Article

\title{
Highly Molybdenum-Alloyed Materials Hastelloy BC-1 (2.4708) and B3 (2.4600): Diffusion Bonding Experiments and Evaluation of both Mechanical Behavior and Corrosion Resistance in Hot $70 \%$ Sulfuric Acid
}

\author{
Thomas Gietzelt ${ }^{1} *$ (D), Mario Walter ${ }^{2}$, Volker Toth ${ }^{1}$, Florian Messerschmidt ${ }^{1}$ and Ralf Dahm ${ }^{2}$ \\ 1 Institute for Micro Process Engineering, Karlsruhe Institute of Technology, 76021 Karlsruhe, Germany; \\ volker.toth@kit.edu (V.T.); florian.messerschmidt@kit.edu (F.M.) \\ 2 Institute for Applied Materials-Solid and Biomechanics, 76021 Karlsruhe, Germany; \\ mario.walter@kit.edu (M.W.); ralf.dahm@kit.edu (R.D.) \\ * Correspondence: thomas.gietzelt@kit.edu; Tel.: +49-721/608-23314
}

Received: 21 February 2020; Accepted: 12 March 2020; Published: 14 March 2020

\begin{abstract}
Sulfuric acid is a widely used raw material in the chemical industry. Its corrosive effect on materials varies considerably, depending on impurities, temperature and water content. This is an issue for micro process apparatuses with thin walls. Such devices are often joint by diffusion bonding what may alter materials properties due to high temperatures and long dwell times. In this paper, two high molybdenum alloys, namely Hastelloy B3 and BC-1, were investigated. Diffusion bonding tests were performed at different temperatures. Tensile tests were carried out for different material conditions, to determine the change in mechanical strength and elongation at fracture values. The fracture behavior of both alloys was ductile and the fracture surfaces showed dimple structure. For diffusion bonded samples, weak spots or rather non-bonded areas were found. These obviously caused the onset of material failure and thus, degradation of mechanical properties. Tensile samples, aged in $70 \%$ sulfuric acid at $100{ }^{\circ} \mathrm{C}$ for $1000 \mathrm{~h}$ showed local corrosion attacks at the grain boundaries at the circumferential surfaces and joining planes-for Hastelloy B3 more pronounced than for Hastelloy BC-1. Accordingly, a further decrease of stress and elongation at fracture values was observed. However, $0.2 \%$ yield strength used for dimensioning components are found to be reasonable. As conclusion, at least Hastelloy BC-1 reveals both good mechanical properties and an excellent corrosion resistance, regardless of the heat treatment. This is a significant advance compared to the results obtained from a previously research project on four different alloys.
\end{abstract}

Keywords: diffusion bonding; Hastelloy B; corrosion; sulfuric acid; micro process device

\section{Introduction}

In addition to blockages caused by by-products resulting from side reactions, corrosion is one of the main reasons for the failure of micro process devices due to the low material thickness. Furthermore, micro process devices are often manufactured from a large number of thin, microstructured sheets, which are mainly joined by diffusion bonding. During processing, they are exposed to high temperatures and long dwell times, which is often associated with a decrease of material strength and formation of precipitations at grain boundaries.

Sulfuric acid is widely used in different concentrations in the chemical industry. Depending on the source and ambient condition during manufacturing, it may contain impurities and a water content that varies within certain limits. During chemical conversion, the strong heat of reactions may occur. 
This can be controlled quite well by micro process devices, which have large surface to volume ratios. For this reason, for a number of years now, various investigations at KIT-IMVT were performed to identify a robust solution for micro-process engineering apparatus in contact with sulfuric acid.

In this paper, two highly molybdenum-alloyed materials, namely Hastelloy B3 and Hastelloy BC-1, were evaluated regarding corrosion resistance in hot $70 \%$ sulfuric acid and eligibility to diffusion bonding.

Molybdenum is known to decrease the surface corrosion in non-oxidizing acids such as sulfuric acid and to improve the pitting corrosion resistance [1-5]. In an earlier AiF-research project (German Federation of Industrial Research Associations) four different materials were characterized with regard to their corrosion behavior (Table 1) [6]. However, the rate of corrosion or material changes were that significant, that the life cycles do not seem to be sufficient enough for micro process devices. In addition, the results were fluctuating and not consistent to different concentrations of sulfuric acid, so that a useful life prediction for micro process devices is not possible.

Table 1. Results of corrosion tests from [6] on four different materials aged in 70 and $95-97 \%$ sulfuric acid at $100{ }^{\circ} \mathrm{C}$ for $1000 \mathrm{~h}$.

\begin{tabular}{|c|c|c|c|c|c|c|}
\hline \multicolumn{7}{|c|}{ Delivery Condition } \\
\hline \multicolumn{2}{|c|}{ Material (DIN/UNS) } & $\begin{array}{c}\text { Concentration } \\
\text { Sulfuric Acid (\%) }\end{array}$ & $\begin{array}{c}\text { Initial } \\
\text { Weight (g) }\end{array}$ & $\begin{array}{c}\text { Final } \\
\text { Weight (g) }\end{array}$ & $\begin{array}{l}\text { Weight } \\
\text { Loss (g) }\end{array}$ & $\begin{array}{l}\text { Weight } \\
\text { Loss (\%) }\end{array}$ \\
\hline 2.4602 & N06022 & 95-97 & 45.464 & 43.867 & 1.597 & 3.5 \\
\hline 2.4605 & N06059 & $95-97$ & 38.796 & 37.823 & 0.973 & 2.5 \\
\hline 2.4692 & N08034 & $95-97$ & 47.094 & 46.385 & 0.709 & 1.5 \\
\hline 2.4700 & N06058 & $95-97$ & 38.124 & 37.776 & 0.348 & 0.9 \\
\hline 2.4602 & N06022 & 70 & 41.444 & 36.345 & 5.099 & 12.3 \\
\hline 2.4605 & N06059 & 70 & 35.025 & 31.586 & 3.439 & 9.8 \\
\hline 2.4692 & N08034 & 70 & 49.217 & 48.748 & 0.469 & 1 \\
\hline 2.4700 & N06058 & 70 & 35.594 & 35.164 & 0.43 & 1.2 \\
\hline \multicolumn{7}{|c|}{ Heat-Treated $1100^{\circ} \mathrm{C} / 4 \mathrm{~h}$} \\
\hline 2.4602 & N06022 & $95-97$ & 38.672 & 37.115 & 1.557 & 4 \\
\hline 2.4605 & N06059 & $95-97$ & 34.652 & 33.355 & 1.297 & 3.7 \\
\hline 2.4692 & N08034 & $95-97$ & 44.701 & 44.095 & 0.606 & 1.4 \\
\hline 2.4700 & N06058 & $95-97$ & 37.594 & 36.489 & 1.105 & 2.9 \\
\hline 2.4602 & N06022 & 70 & 40.332 & 36.03 & 4.302 & 10.7 \\
\hline 2.4605 & N06059 & 70 & 37.42 & 32.636 & 4.784 & 12.8 \\
\hline 2.4692 & N08034 & 70 & 46.404 & 39.763 & 6.641 & 14.3 \\
\hline 2.4700 & N06058 & 70 & 41.436 & 38.56 & 2.876 & 6.9 \\
\hline
\end{tabular}

Even for Alloy $2120 \mathrm{MoN}$ (2.4700) produced by VDM Metals International GmbH, Werdohl, Germany containing comparable high contents of molybdenum, no good results were obtained, despite it showed the lowest corrosion rate in $70 \%$ sulfuric acid at $100^{\circ} \mathrm{C}$, especially in the heat-treated condition.

Also coating concepts, such as tantalization, were investigated to improve the corrosion resistance of micro process devices [7]. However, it has to be stated that any coating solution is susceptible to mechanical damaging in harsh industrial environments.

\section{Materials and Design of Experiments}

Hastelloy B3 and BC-1 are highly molybdenum-alloyed materials. In Table 2, physical properties and the composition of these alloys are given, together with values of Alloy $2120 \mathrm{MoN}$ for comparison reasons.

It needs to be mentioned, that all materials reveal a cubic face-centered lattice (fcc). However, due to the high content of molybdenum and according to Grüneisen's Rule, in contrast to ordinary austenitic stainless steels, the coefficient of thermal expansion is more comparable to that of ferritic steels. While Hastelloy BC-1 has a clearly higher chromium content than Hastelloy B3, B3 contains significantly more molybdenum. 
Table 2. Physical properties and chemical composition of Hastelloy B3, Hastelloy BC-1, and Alloy 2120 MoN [8-10].

\begin{tabular}{cccc}
\hline Alloy (\%) & B3 & BC-1 & Alloy 2120 MoN \\
\hline EN & 2.4600 & 2.4708 & 2.4700 \\
UNS & N10675 & N10362 & N06058 \\
Melting Range $\mathrm{T}_{\mathrm{M}}\left({ }^{\circ} \mathrm{C}\right)$ & $1370-1418$ & $1343-1443$ & $1330-1370$ \\
Thermal Conductivity $\alpha\left(\mathrm{W} / \mathrm{m}^{*} \mathrm{~K}\right)$ & 11.2 & 9.3 & 9.8 \\
Mean Coefficient of Thermal & 10.6 & 11.5 & 11.44 \\
Expansion $\lambda\left({ }^{*} 10^{-6} \mathrm{~K}^{-1}\right)\left[25-100{ }^{\circ} \mathrm{C}\right]$ & Bal. & Bal. & Bal. \\
$\mathrm{Ni}$ & 28.5 & 22 & $18.5-21$ \\
$\mathrm{Mo}$ & 1.5 & 15 & $20-23$ \\
$\mathrm{Cr}$ & 1.5 & $<2$ & $<1.5$ \\
$\mathrm{Fe}$ & $<3$ & 0.3 \\
$\mathrm{~W}$ & $<3$ & $<1$ & $<0.5$ \\
$\mathrm{Mn}$ & $<3$ & $<0.5$ & $<0.3$ \\
$\mathrm{Co}$ & $<0.5$ & & $<0.4$ \\
$\mathrm{Al}$ & $<0.2$ & $<0.08$ & $<0.1$ \\
$\mathrm{Ti}$ & $<0.1$ & $<0.01$ & $<0.01$ \\
$\mathrm{Si}$ & $<0.01$ & & $<0.5$ \\
$\mathrm{C}$ & $<0.2$ & & \\
$\mathrm{Nb}$ & $<0.2$ & & $0.02-0.15$ \\
$\mathrm{~V}$ & $<0.2$ & & \\
$\mathrm{Cu}$ & $<0.2$ & & \\
$\mathrm{Ta}$ & $<0.01$ & & \\
$\mathrm{Zr}$ & & & \\
$\mathrm{N}$ & & & \\
& & & \\
\hline
\end{tabular}

For Hastelloy B3, the yield strength at room temperature in solution annealed condition is ranging from 400 to $421 \mathrm{MPa}$, depending on form of delivery. The tensile strength is specified with $862-883 \mathrm{MPa}$, while the elongation at fracture varies between $53 \%$ and $58 \%$. For solution annealing, a temperature of $1066^{\circ} \mathrm{C}$ is recommended.

For Hastelloy BC-1, the yield strength at room temperature in solution annealed condition ranges from 362 to $405 \mathrm{MPa}$, depending on the thickness of semi-finished products. The tensile strength varies between 809 and $841 \mathrm{MPa}$, while the elongation at fracture varies between 61.6 and $70.5 \%$. For solution annealing, a much higher temperature than for Hastelloy B3, namely $1149^{\circ} \mathrm{C}$, is recommended.

For the corrosion experiments, coupons of Hastelloy B3 and BC-1, containing a TIG weld and made of $3 \mathrm{~mm}$ thick sheet metal, were provided by HAYNES. Using a disk cutter from ATM Qness $\mathrm{GmbH}$, Mammelzen, Germany, type Brillant 250, pieces with a size of approximately $20 \times 80 \mathrm{~mm}^{2}$ and $40 \mathrm{~g}$ in weight were cut. One set of specimens was investigated in condition as delivered. A second set of specimens was placed inside a diffusion bonding furnace during a run to simulate a heat treatment. For this purpose, a temperature of $\mathrm{T}=1100^{\circ} \mathrm{C}$ was applied for $\mathrm{t}=4 \mathrm{~h}$. Subsequently, the samples were cooled down in diffusion bonding furnace 2 . Figure 1 shows the cooling behavior of three diffusion bonding furnaces of different sizes with $20 \mathrm{kN}, 200 \mathrm{kN}$, and $2 \mathrm{MN}$ compressive load, respectively, available at IMVT. It can be seen that the cooling rate of furnace 2 at approx. $600{ }^{\circ} \mathrm{C}$ falls below $5 \mathrm{~K} / \mathrm{min}$, which is half of the heating rate. This facilitates sensitization, especially with nickel-based alloys, which has an impact on corrosion behavior in aggressive media [11-13].

The main point of criticism of the authors with regard to the investigation of intergranular corrosion according to ASTM G-28A-02 (2015) for micro process apparatus is the short alloy-specific test duration and the determination of a specific corrosion medium and temperature [14]. If we further realize that the criterion for the derivation of the sensitization diagrams is a corrosion attack depth of $50 \mu \mathrm{m}$ under the above-mentioned conditions, the test does not provide any helpful information on the suitability of a material in micro-process engineering where dimensions below $1 \mathrm{~mm}$ wall thickness 
need to be realized. Significantly longer test periods are required to obtain reliable results. For this reason, a test duration of $1000 \mathrm{~h}$ was specified.

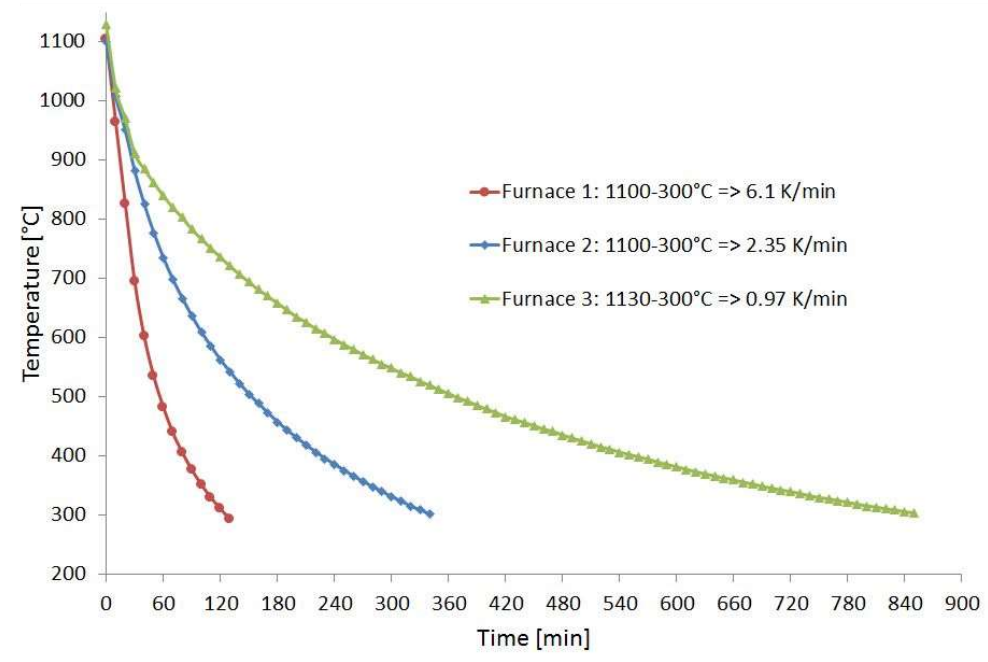

Figure 1. Temperature profile of the used diffusion bonding furnaces.

For initial diffusion bonding experiments, sheet material of Hastelloy BC-1 and Hastelloy B3 were supplied by HAYNES, $1.0 \mathrm{~mm}$ and $1.6 \mathrm{~mm}$ in thickness, respectively. From these sheets, 10 pieces-each $20 \times 20 \mathrm{~mm}^{2}$ in size-were cut using a TruLaser Cell 3010, combined with a $3 \mathrm{~kW}$ TruDisk 3001 (TRUMPF GmbH + Co. KG, Ditzingen, Germany).

Round stock of different diameters from both alloys was used to produce the initial material with a diameter of $30 \mathrm{~mm}$ by wire erosion. Additional, for both materials, ten disks, $30 \mathrm{~mm}$ in diameter, were cut by laser from sheet material. To ensure a reasonable initial height of the diffusion bonding specimens related to the preparation of tensile specimens, two pieces of round stock with a height of $15 \mathrm{~mm}$ and $17 \mathrm{~mm}$ for Hastelloy B3 and Hastelloy BC-1, respectively, were prepared. In between, 10 layers of sheet material were stacked, giving an absolute height of $46 \mathrm{~mm}$ and $44 \mathrm{~mm}$, respectively (Figure 2).

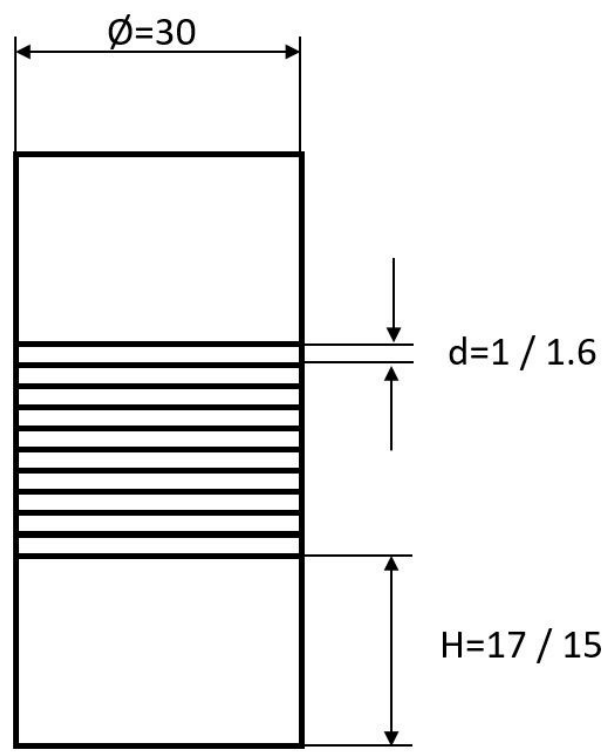

Figure 2. Diffusion bonding samples used for preparing tensile test specimens. All dimensions are given in millimeters. 


\section{Experiments and Results}

\subsection{Diffusion Bonding Experiments on Hastelloy B3 and BC-1}

\subsubsection{Initial Diffusion Bonding Experiments Made of Ten Sheets}

Based on empirical values, initial diffusion bonding tests were carried out for both alloys. The parameters used are listed in Table 3. The dwell time was chosen to be $\mathrm{t}=4 \mathrm{~h}$ in all experiments. Diffusion bonding experiments were performed in furnace I $(20 \mathrm{kN})$. Due to different sheet material thickness of 1.0 and $1.6 \mathrm{~mm}$, respectively, the aspect ratio $(\mathrm{d} / \mathrm{h})$ was 0.8 and 0.5 for 10 sheets of $20 \times 20 \mathrm{~mm}^{2}$. Deformation values are very similar for both materials. Furthermore, the deformation depends on the aspect ratio: Hence, for Hastelloy B3 with a sheet thickness of $1.6 \mathrm{~mm}$ and an aspect ratio of 0.8 , a slightly higher deformation was expected than for Hastelloy BC-1 [15]. However, due to the low absolute value, the measurement error may be higher than for a larger heights and deformation values.

Table 3. Diffusion bonding parameters for Hastelloy B3 and BC-1 and resulting deformations.

\begin{tabular}{cccccc}
\hline Temperature $\left({ }^{\circ} \mathbf{C}\right)$ & Surface Pressure (MPa) & Initial Height $(\mathbf{m m})$ & Final Height $(\mathbf{m m})$ & Deformation $(\mathbf{m m})$ & Deformation $(\%)$ \\
\hline \multicolumn{7}{c}{ Hastelloy B3 } \\
\hline 1100 & 14 & 16.134 & 15.904 & 0.23 \\
1150 & 10 & 16.152 & 15.998 & 0.154 & 0.11 \\
1200 & 6 & 16.146 & 16.036 & 0.95 \\
\hline \multicolumn{7}{c}{ Hastalloy BC-1 } \\
\hline 1100 & 14 & 10.316 & 10.176 & 0.14 \\
1150 & 10 & 10.312 & 10.218 & 0.094 & 0.082 \\
\hline
\end{tabular}

It turned out that the deformation decreases with increasing bonding temperature, since the temperature increase of $50 \mathrm{~K}$ for subsequent experiments was overcompensated by decreasing the contact pressure as depicted in Table 3.

According to Figure 3, the grain size for Hastelloy B3 increases with increasing diffusion bonding temperature. At $\mathrm{T}=1100{ }^{\circ} \mathrm{C}$, some pores could be observed. Obviously, the surface pressure of $\mathrm{p}=14 \mathrm{MPa}$ was not sufficient. Probably due to passivation layers, even at $\mathrm{T}=1200^{\circ} \mathrm{C}$, only the first signs of grain growth over the joining planes were visible.
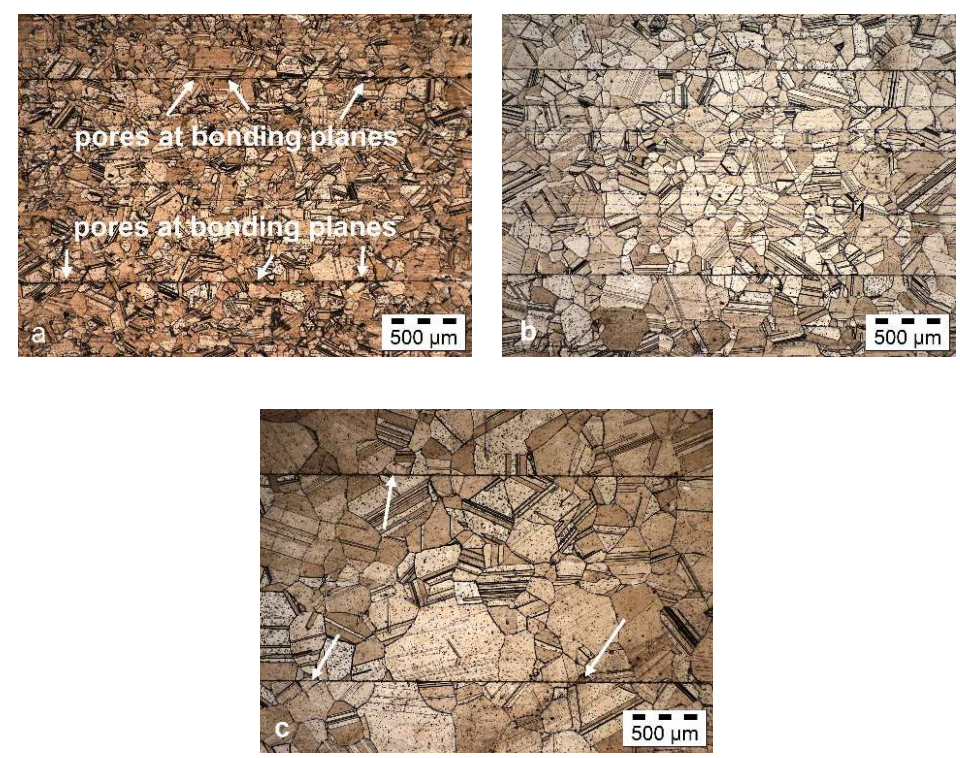

Figure 3. Resulting microstructure of Hastelloy B3 after diffusion bonding for $\mathrm{t}=4 \mathrm{~h}$ at $(\mathbf{a}) \mathrm{T}=1100^{\circ} \mathrm{C}$; (b) $\mathrm{T}=1150{ }^{\circ} \mathrm{C}$; and (c) $\mathrm{T}=1200{ }^{\circ} \mathrm{C}$. 
In contrast, for Hastelloy $\mathrm{BC}-1$, even for $\mathrm{T}=1100^{\circ} \mathrm{C}$ grain growth across the bonding plane can be seen (Figure 4a). However, the microstructure shows strong discontinuous grain growth with a bimodal grain size distribution. For $\mathrm{T}=1200{ }^{\circ} \mathrm{C}$, strong grain growth was observed.
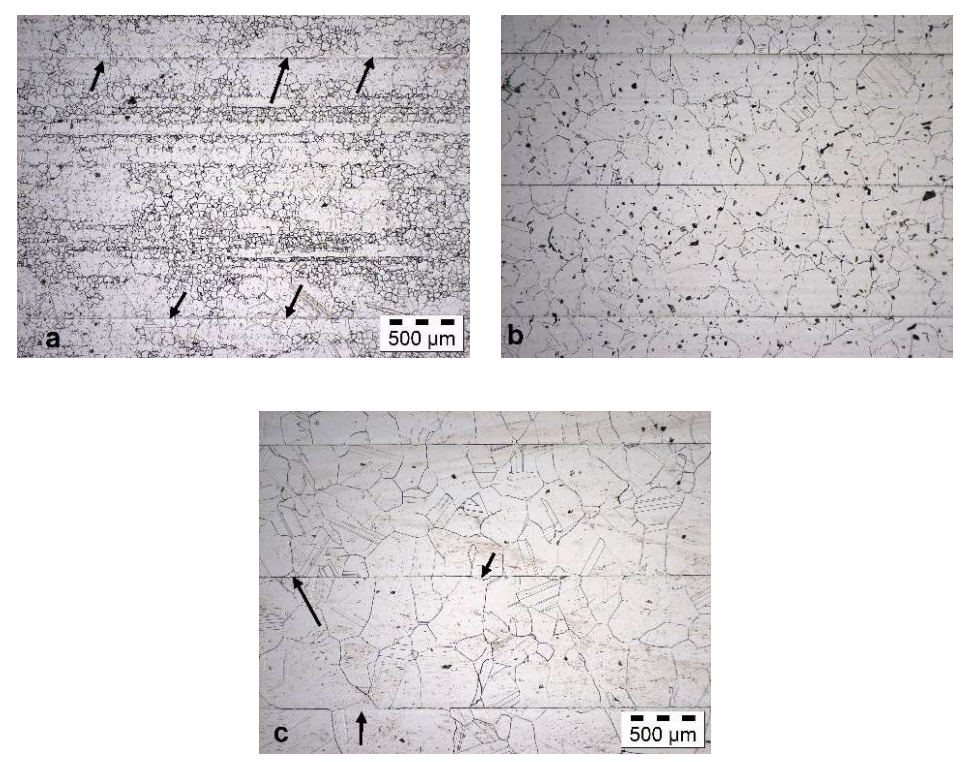

Figure 4. Resulting microstructure of Hastelloy BC-1 after diffusion bonding for $\mathrm{t}=4 \mathrm{~h}$ at $(\mathbf{a}) \mathrm{T}=1100^{\circ} \mathrm{C}$; (b) $\mathrm{T}=1150{ }^{\circ} \mathrm{C}$; and (c) $\mathrm{T}=1200{ }^{\circ} \mathrm{C}$.

In [16] with a similarly composed high-temperature alloy (alloy 617, 2.4663); however, it was shown that it is possible to achieve good grain growth across the joining plane, without giving any bonding parameters.

\subsubsection{Diffusion Bonding Experiments for Manufacturing Tensile Test Specimens}

Based on the results of the initial diffusion bonding tests, the bonding temperature for the diffusion bonding cycle to produce tensile test specimen was set to $\mathrm{T}=120{ }^{\circ} \mathrm{C}$. The dwell time was kept constant with $\mathrm{t}=4 \mathrm{~h}$ but the contact pressure was increased from $\mathrm{p}=6 \mathrm{MPa}$ to $10 \mathrm{MPa}$ (bulk samples for comparison were placed next to the diffusion bonding samples in the same batch). Taking into account the different geometry of the diffusion bonding sample for tensile test specimen, featuring an aspect ratio of about 1.5, more deformation and facilitating breakthrough the passivation layer was expected.

However, despite the contact pressure was increased by $66 \%$ compared to initial diffusion bonding experiments, the deformation was found to be only $2.03 \%$ and $2.06 \%$ for Hastelloy B3 and Hastelloy $\mathrm{BC}-1$, respectively. This result shows again the impact of the sample geometry as well as the size of the absolute cross-section of the surfaces to be joined on deformation.

\subsection{Corrosion Experiments in Sulfuric Acid at $100^{\circ} \mathrm{C}$}

\subsubsection{Corrosion Test on Coupons aged in $70 \%$ Sulfuric Acid}

For corrosion tests, the specimen was placed on a bridge made of PTFE (polytetrafluorethylene) inside a beaker with a volume of $800 \mathrm{~mL} .500 \mathrm{~mL}$ of $70 \%$ sulfuric acid was added, diluted from 95-97\% sulfuric acid, supplied by Merck KGaA, Darmstadt, Germany. The beakers were wrapped with rock wool and a lid made of PTFE was used for thermal insulation. A magnetic stirrer was placed under the PTFE bridge. A speed of $120 \mathrm{rpm}$ was set for the stirrer. The beakers were controlled every week, however, no green color, due to solved nickel ions was observed.

$70 \%$ sulfuric acid is considered to be more corrosive than $95-97 \%$ sulfuric acid because of its water content. Compared to the results obtained for the other four alloys shown in Table 1, especially for the 
heat-treated condition, for Hastelloy BC-1, superior results were obtained. In Figure 5 it can be seen that the surface of Hastelloy BC-1 has remained almost unchanged, while the surface of Hastelloy B3 shows some pitting attack. In Table 4, weight losses of all samples in $70 \%$ sulfuric acid are given.

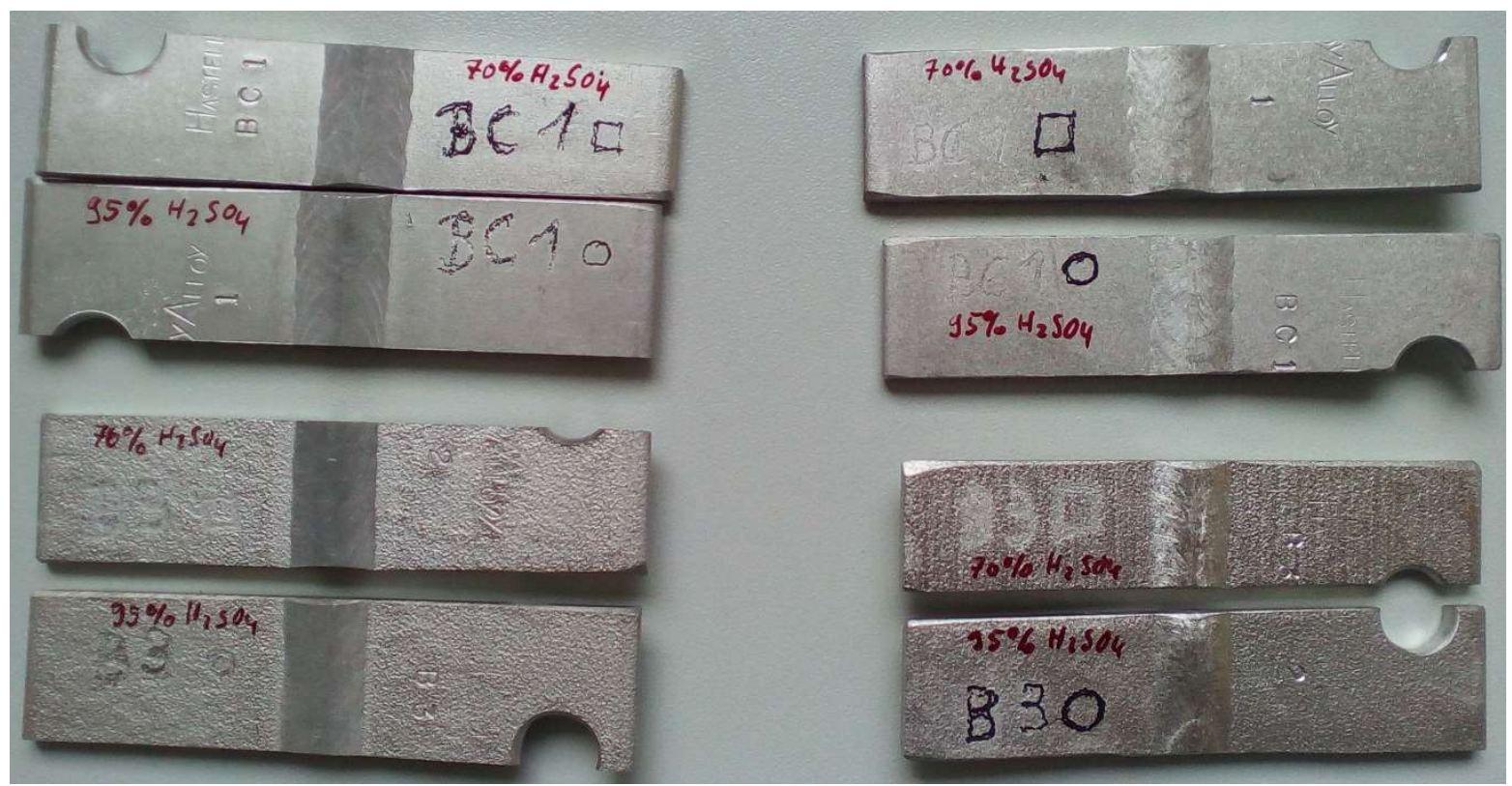

Figure 5. Test specimens after corrosion tests. Left: Condition as delivered. Right: Heat-treated $\left(\mathrm{T}=1100{ }^{\circ} \mathrm{C}, \mathrm{t}=4 \mathrm{~h}\right)$. Top: Hastelloy BC-1. Bottom: Hastelloy B3.

Table 4. Results of corrosion experiments of coupons aged in $70 \%$ sulfuric acid.

\begin{tabular}{|c|c|c|c|c|c|c|}
\hline Material & UNS & Condition & $\begin{array}{c}\text { Initial } \\
\text { Weight (g) }\end{array}$ & $\begin{array}{c}\text { Final } \\
\text { Weight (g) }\end{array}$ & $\begin{array}{l}\text { Weight } \\
\text { Loss (g) }\end{array}$ & $\begin{array}{l}\text { Weight } \\
\text { Loss (\%) }\end{array}$ \\
\hline B3/2.4600 & N06022 & \multirow{2}{*}{$\begin{array}{l}\text { Delivery } \\
\text { Condition }\end{array}$} & 39.673 & 39.327 & 0.346 & 0.87 \\
\hline BC-1/2.4708 & N08034 & & 37.278 & 36.922 & 0.356 & 0.95 \\
\hline B3/2.4600 & N06022 & \multirow{2}{*}{$\begin{array}{l}\text { Heat-treated } \\
1100{ }^{\circ} \mathrm{C} / 4 \mathrm{~h}\end{array}$} & 34.713 & 33.773 & 0.94 & 2.71 \\
\hline BC-1/2.4708 & N08034 & & 40.845 & 40.524 & 0.321 & 0.79 \\
\hline
\end{tabular}

\subsubsection{Corrosion Test at Coupons aged in 95-97\% Sulfuric Acid}

As expected, in concentrated sulfuric acid the corrosion is less pronounced than in $70 \%$ sulfuric acid. Especially in the heat-treated condition, both materials exhibit a very low weight loss that is even lower than in the as delivered condition. However, due to low mass loss, it may be attributed to the error of measurement. The weight losses of all samples in 95-97\% sulfuric acid are given in Table 5.

Table 5. Results of corrosion experiments in 95-97\% sulfuric acid.

\begin{tabular}{|c|c|c|c|c|c|c|}
\hline Material & UNS & Condition & $\begin{array}{c}\text { Initial } \\
\text { Weight (g) }\end{array}$ & $\begin{array}{c}\text { Final } \\
\text { Weight (g) }\end{array}$ & $\begin{array}{l}\text { Weight } \\
\text { Loss (g) }\end{array}$ & $\begin{array}{l}\text { Weight } \\
\text { Loss (\%) }\end{array}$ \\
\hline B3/2.4600 & N06059 & \multirow{2}{*}{$\begin{array}{c}\text { Delivery } \\
\text { condition }\end{array}$} & 40.403 & 40.209 & 0.194 & 0.48 \\
\hline BC-1/2.4708 & N06058 & & 41.139 & 40.734 & 0.405 & 0.98 \\
\hline B3/2.4600 & N06059 & \multirow{2}{*}{$\begin{array}{l}\text { Heat-treated } \\
1100{ }^{\circ} \mathrm{C} / 4 \mathrm{~h}\end{array}$} & 37.692 & 37.55 & 0.142 & 0.38 \\
\hline BC-1/2.4708 & N06058 & & 37.274 & 37.062 & 0.212 & 0.57 \\
\hline
\end{tabular}




\subsubsection{Corrosion Test at Tensile Test Samples aged in 70\% Sulfuric Acid}

In a second series of tests, five diffusion bonded tensile test specimens from Hastelloy B3 and $\mathrm{BC}-1$, respectively, were aged in $70 \%$ sulfuric acid at $100{ }^{\circ} \mathrm{C}$ for $1000 \mathrm{~h}$ to investigate the impact of corrosion on the mechanical properties. This is an important aspect in order to assess the integrity of micro process devices as a function of corrosion phenomena over their lifetime. The corrosion traces of the SEM-pictures at the circumferential surface of both alloys showed no strong differences (Figure 6). There is some corrosion attack at grain boundaries. Only a few grain growths across the bonding plane could be observed. Instead, pronounced decoration by corrosion of original bonding planes was observed. Probably, the deformation of approximately $2 \%$ and 11 bonding planes is not sufficient to level surface roughness and to break passivation layers.

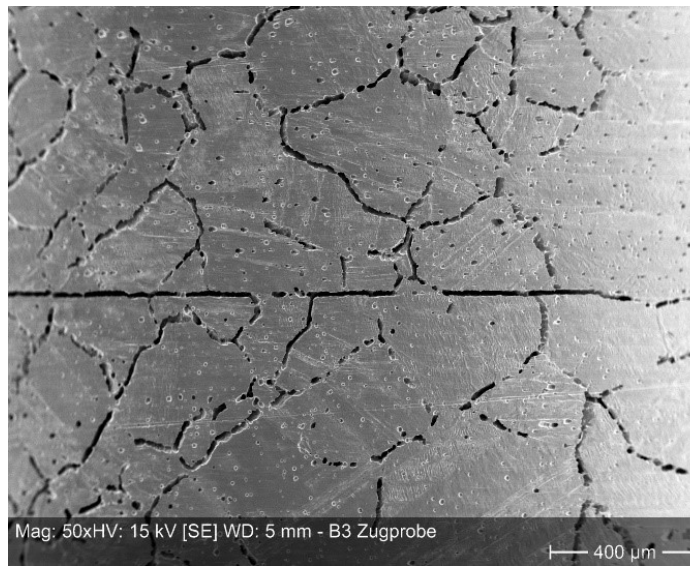

(a)

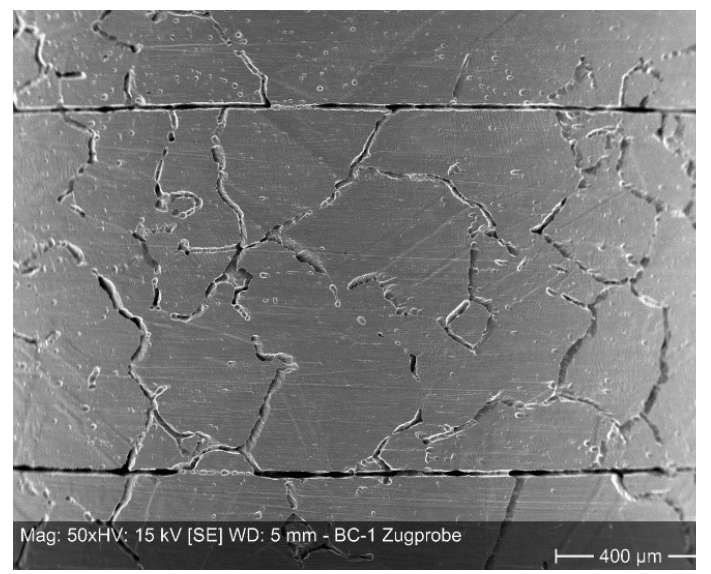

(b)

Figure 6. Surface of tensile specimens from Hastelloy B3 (a) and Hastelloy BC-1 (b) after exposure to $70 \%$ sulfuric acid at $100{ }^{\circ} \mathrm{C}$ for $1000 \mathrm{~h}$.

\subsection{Tensile Tests on both Hastelloy B3 and BC-1}

\subsubsection{Material Conditions}

For tensile tests, four different treated specimen types were prepared for both alloys:

1. Bulk samples in as-delivered condition;

2. Bulk samples heat-treated at $\mathrm{T}=1200^{\circ} \mathrm{C}$ for $\mathrm{t}=4 \mathrm{~h}$ and loaded with $\mathrm{p}=10 \mathrm{MPa}$ in compression;

3. Diffusion bonded specimens with 10 layers of sheet material processed at $\mathrm{T}=1200{ }^{\circ} \mathrm{C}$ for $\mathrm{t}=4 \mathrm{~h}$ with $\mathrm{p}=10 \mathrm{MPa}$ in compression;

4. Diffusion bonded specimens processed as described in 3, additionally aged in $70 \%$ sulfuric acid at $100{ }^{\circ} \mathrm{C}$ for $1000 \mathrm{~h}$.

\subsubsection{Tensile Specimen Geometry and Test Method}

The geometry of tensile test specimens is shown in Figure 7. Tensile tests were performed displacement controlled $(\mathrm{dl} / \mathrm{dt}=2 \mathrm{~mm} / \mathrm{min}$ ) at RT (room temperature) using a universal testing machine from Instron (type 4505), equipped with a controller unit from Doli. In order to take into account scatter issues, five tests per treatment condition were carried out. 


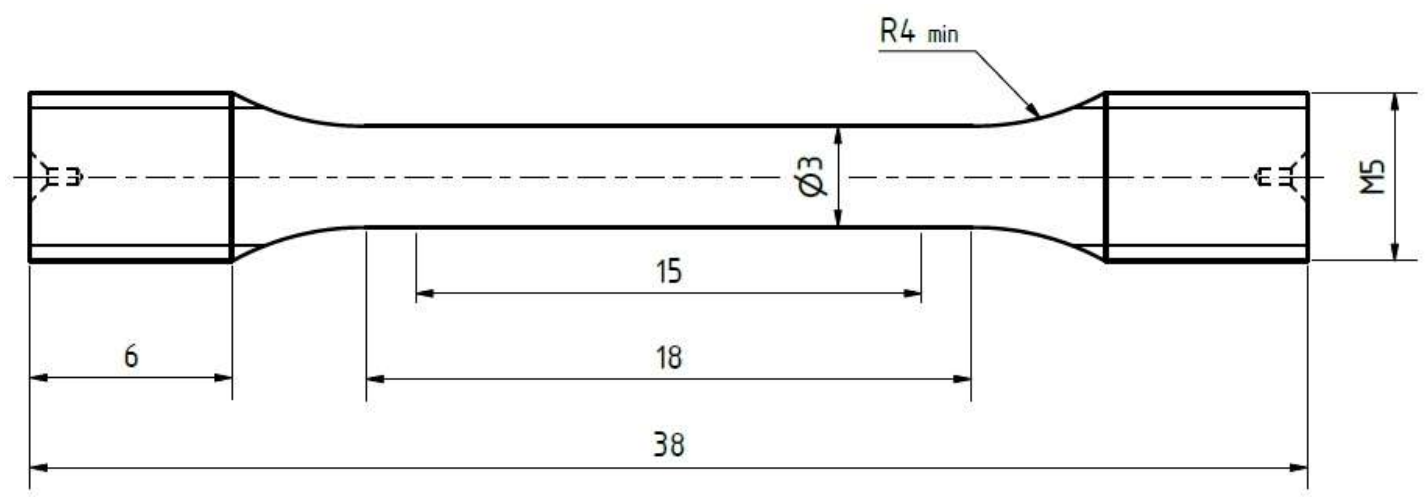

Figure 7. Geometry of the tensile specimens. All dimensions are given in millimeters.

\subsubsection{Results of Tensile Tests on Hastelloy B3}

In Figure 8, the results of the tests on as delivered-, heat-treated, and compressed- and diffusion-bonded samples are depicted. When comparing the as delivered condition of bulk material with the heat-treated condition it can be seen that the annealed samples show a decrease in strength of about $20-25 \%$ and an increase in ductility of about $20 \%$. Accordingly, the annealed material reveals a slightly less pronounced hardening behavior. The change in deformation behavior can be generally traced back on both recovery and recrystallization/grain growth processes (compare Figures 3 and 4) occurring during exposure to high temperature.

Compared to the heat-treated bulk samples, the diffusion bonded samples exhibit a comparable deformation behavior but a significant decrease in elongation at fracture of about $50 \%$ on average. The earlier onset of failure is obviously a result of several weak spots within the bonding planes in the form of non-bonded areas that act as cracks.

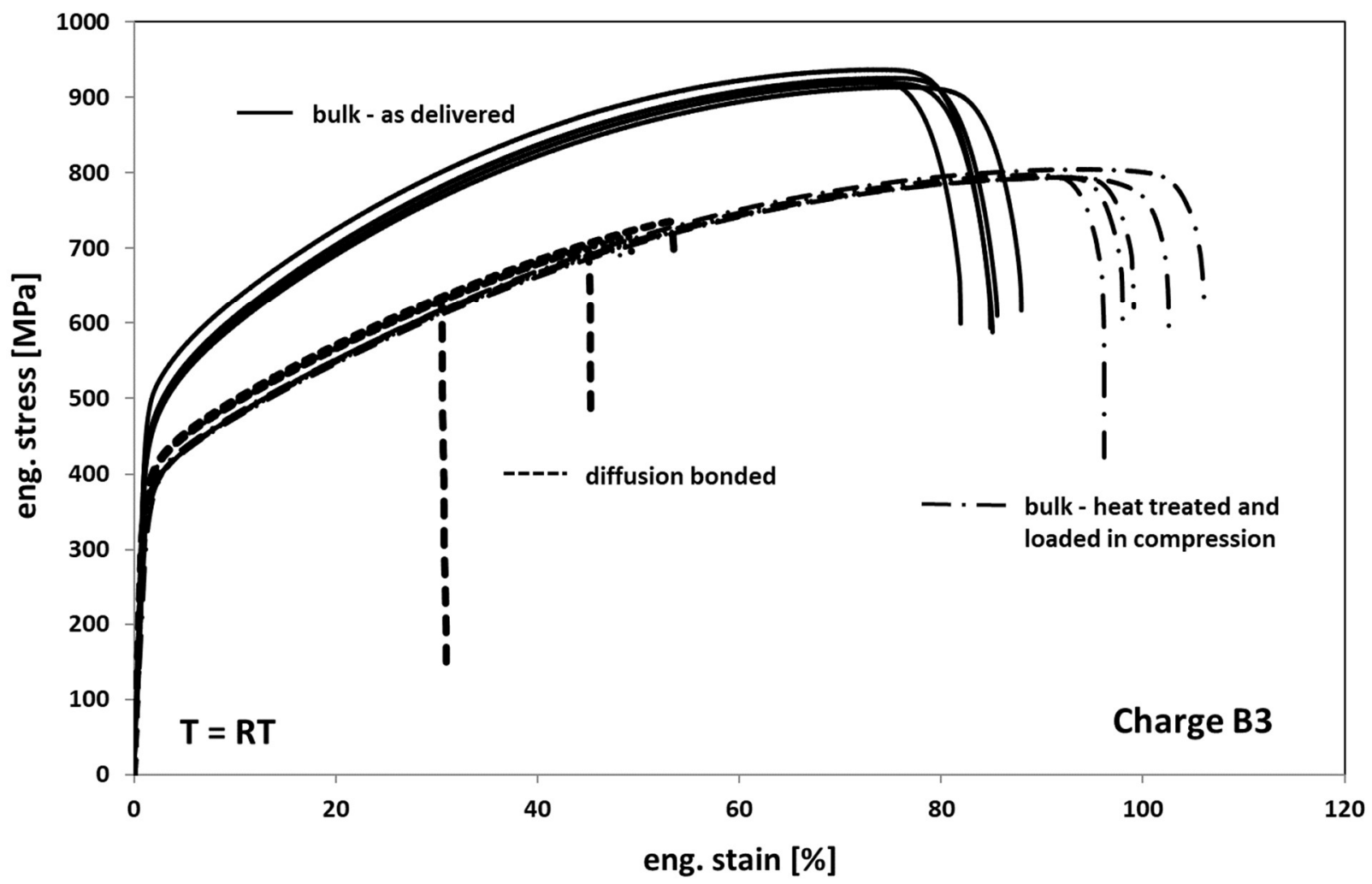

Figure 8. Tensile response of Hastelloy B3 in different conditions. 
Examples of such weak spots based on scratches or dents etc. on the individual sheets are shown in Figure 9. In Figure 9a,b one can see an overview of fracture surfaces exhibiting a multitude of weak spots. When comparing both micrographs it becomes clear, that the high scatter of the elongation at fracture values is related to the entire size of the non-bonded areas, lowering the real load bearing cross-sections. While sample 5, depicted in Figure $9 \mathrm{~b}$, reveals an elongation at fracture of approximately $30 \%$, sample 3, depicted in Figure 9a, reveals an elongation at fracture of almost 50\%. A closer view on a fracture surface (Figure 9c) is manifesting the general ductile nature of failure within well bonded sections in form of dimples, here, surrounding a weak spot. Non-bonded areas are also located at the surface of a sample. Accordingly, with increasing deformation the occurrence of smaller surface cracks is visible in several bonding planes (Figure 9d).

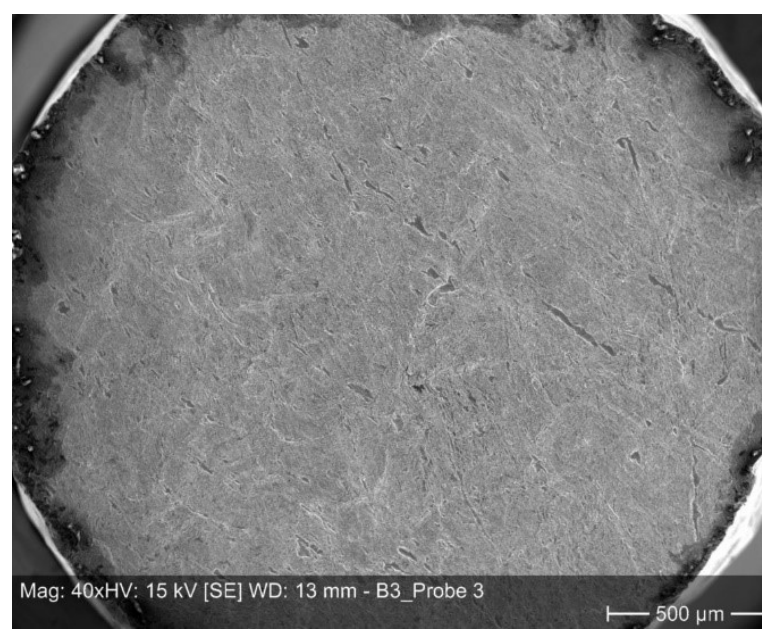

(a)

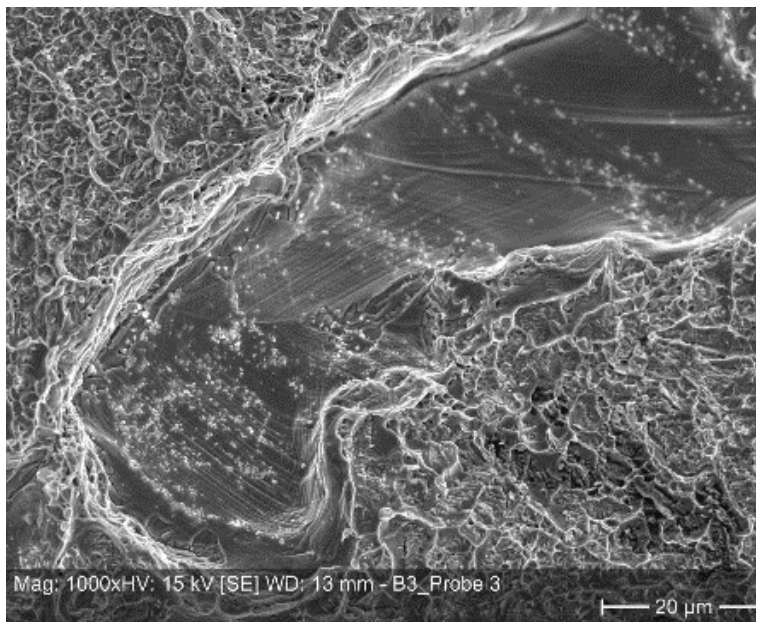

(c)

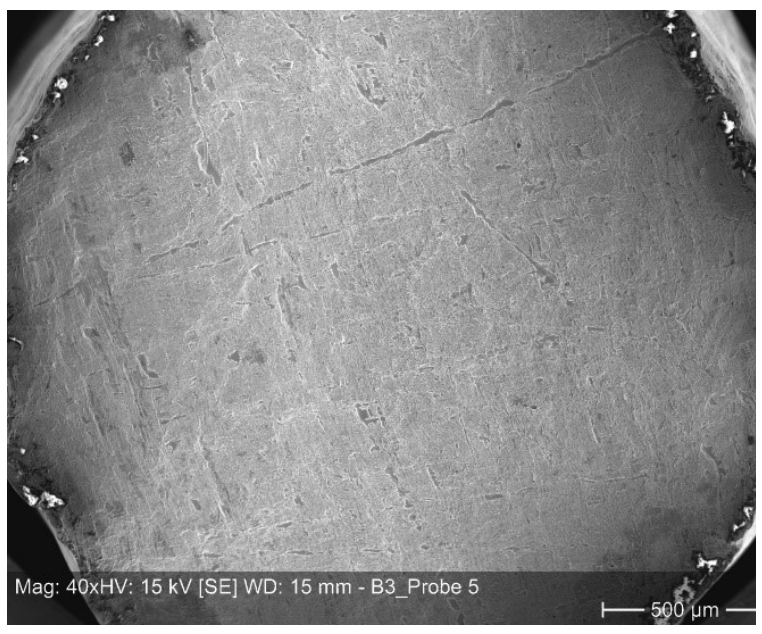

(b)

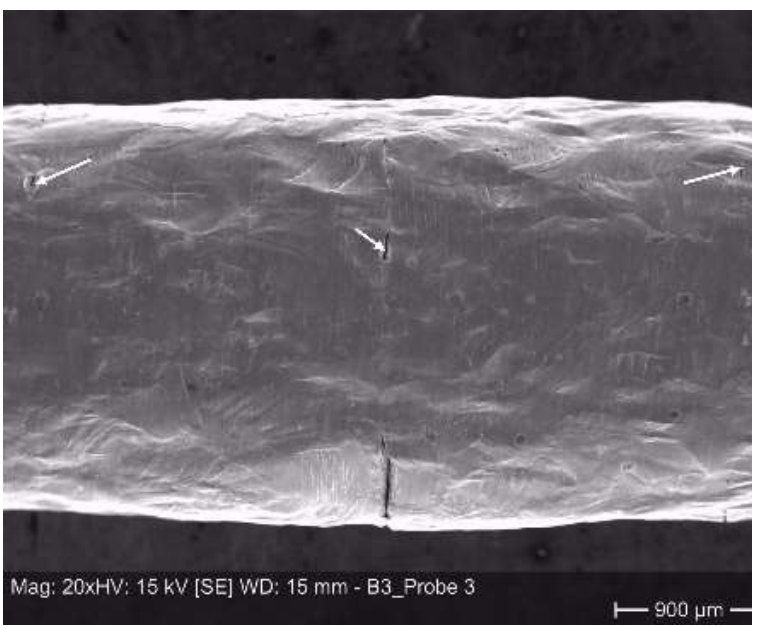

(d)

Figure 9. Micrographs of tensile tested diffusion bonded samples-(a) and (b): overview of fracture surfaces; (c): ductile fracture area surrounding a weak spot; and (d): small surface cracks located at different bonding planes. 
When comparing the tensile test results obtained from tests on diffusion bonded samples, aged for $1000 \mathrm{~h}$ at $100{ }^{\circ} \mathrm{C}$ in $70 \%$ sulfuric acid with the results obtained on non-aged bonded samples (Figure 10), one can see a further strong decrease of the elongation at fracture to an average value of about $20 \%$. Additionally, the stress level also significantly decreased (Figure 10, interrupted grey deformation curves). However, this finding is based on the fact, that the stress calculation of the engineering stress is usually related to the nominal initial cross-section. In fact, based on a much stronger corrosive attack into the volume than expected when viewing Figure 6a, a real initial cross-section after aging is much smaller as one can see in Figure 11. Accordingly, by determining the average depth of the corrosion cracks inside the failed bonding planes, the initial cross-sections and subsequently the stresses were re-calculated. Now, the stress level of aged samples is significantly higher than the one of non-aged samples (Figure 10, black deformation curves). This might be related to the formation of an inhomogeneous distributed multiaxial stress-strain-field during loading-see Figure 11c, concave shaped surface between the bonding planes. The pronounced notch effect and the resulting stress concentrations can also explain the decrease of the elongation at fracture values.

An overview of the obtained mechanical properties of all tested specimens is given in Table 6. The obtained stresses are related to the true initial cross-sections.

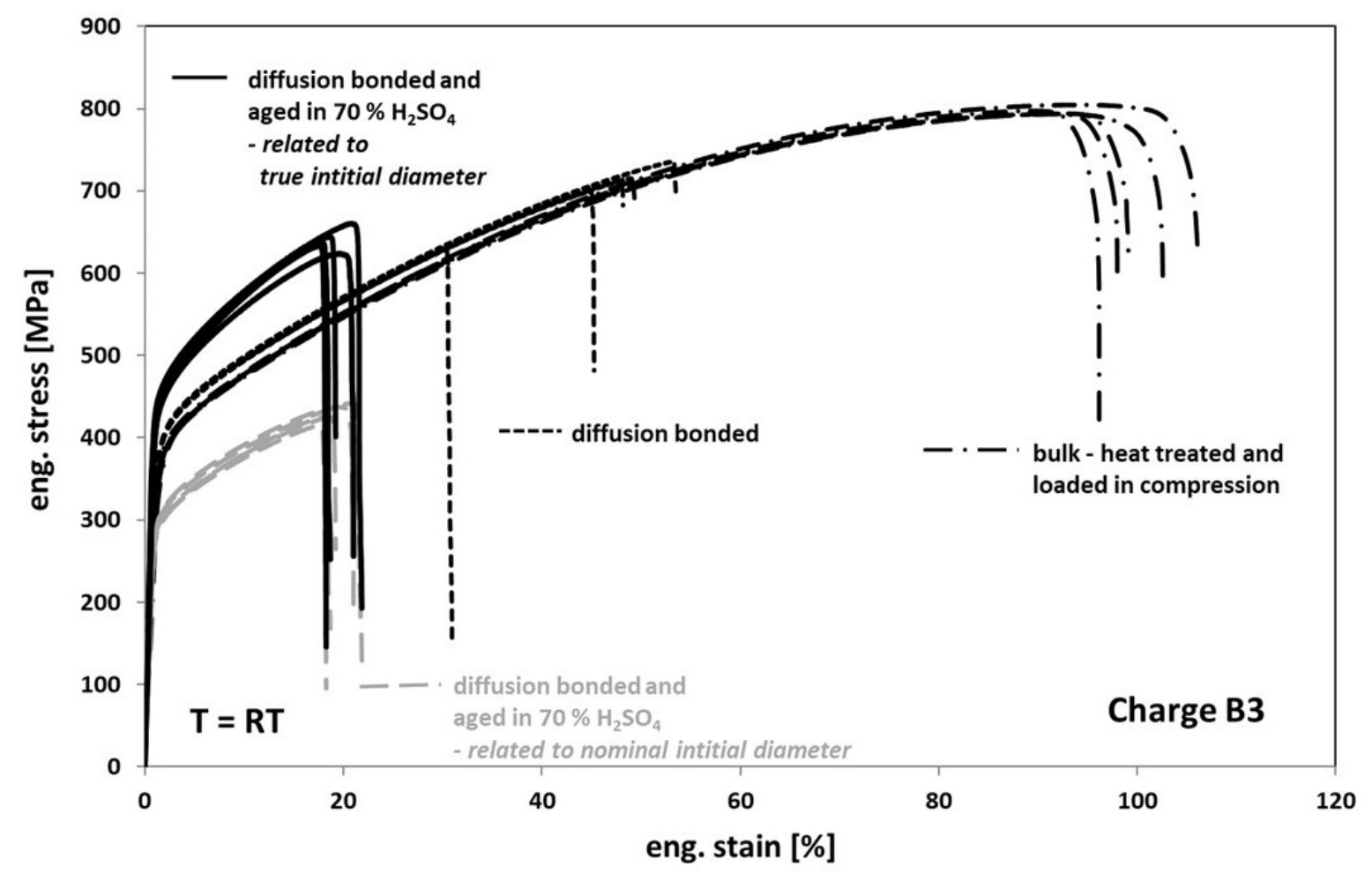

Figure 10. Tensile response of Hastelloy B3 in different conditions. 

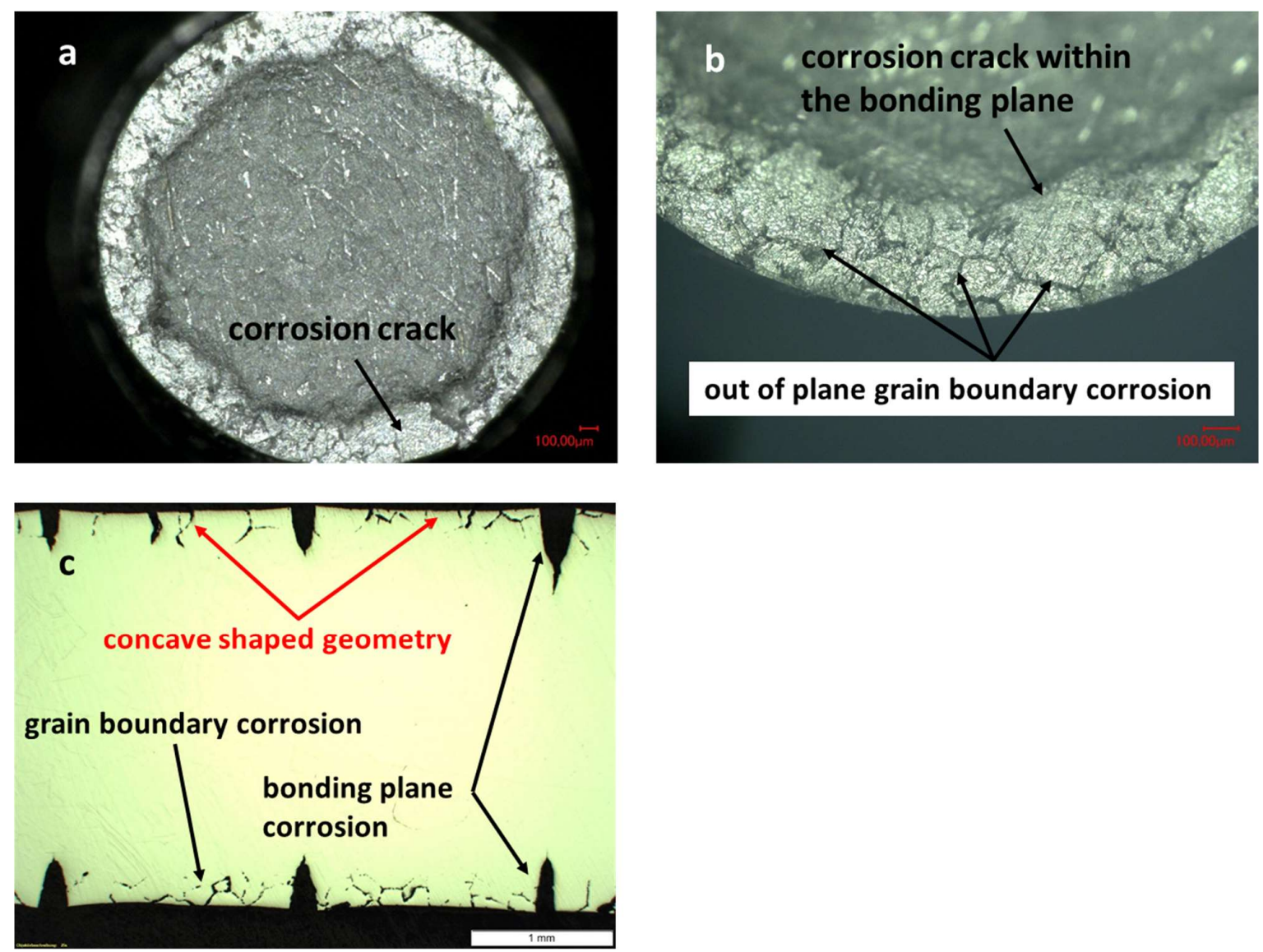

Figure 11. Micrographs of tensile tested diffusion bonded and aged $\left(1000 \mathrm{~h}\right.$ at $100{ }^{\circ} \mathrm{C}$ in $70 \%$ sulfuric acid) samples made of Hastelloy B3. (a): Overview of fracture surface displaying corrosion attack depth. (b): Border of corrosion attack depth and out of plane grain boundary corrosion. (c): Longitudinal cut along center of failed sample. Since no tensile forces can be transmitted to the depth of the corrosion attack and only the core diameter has been stretched, the outer areas experience compressive stresses and show concave deformation.

Table 6. Mechanical properties of Hastelloy B3 tested in different conditions.

(A) Yield strength and tensile strength.

\begin{tabular}{|c|c|c|c|c|c|c|c|c|}
\hline \multirow{2}{*}{ Sample-No } & \multicolumn{2}{|c|}{ As-Delivered } & \multicolumn{2}{|c|}{$\begin{array}{c}\text { Heat-Treated } \\
1200^{\circ} \mathrm{C} / 4 \text { h with } \\
\text { Contact Pressure }\end{array}$} & \multicolumn{2}{|c|}{$\begin{array}{l}\text { Diffusion Bonded } \\
1200{ }^{\circ} \mathrm{C} / 4 \mathrm{~h} / 10 \mathrm{MPa}\end{array}$} & \multicolumn{2}{|c|}{$\begin{array}{c}\text { Diffusion Bonded } \\
1200{ }^{\circ} \mathrm{C} / 4 \mathrm{~h} / 10 \mathrm{MPa}+ \\
1000 \mathrm{~h} 70 \% \mathrm{H}_{2} \mathrm{SO}_{4} @ \\
100{ }^{\circ} \mathrm{C}\end{array}$} \\
\hline & $\begin{array}{c}\text { Yield } \\
\text { Strength } \\
\mathbf{R}_{\mathrm{p} 0.2} \\
{[\mathrm{MPa}]}\end{array}$ & $\begin{array}{c}\text { Tensile } \\
\text { Strength } \\
\mathbf{R}_{\mathrm{m}} \\
{[\mathrm{MPa}]}\end{array}$ & $\begin{array}{c}\text { Yield } \\
\text { Strength } \\
\mathbf{R}_{\mathrm{p} 0.2} \\
{[\mathrm{MPa}]}\end{array}$ & $\begin{array}{c}\text { Tensile } \\
\text { Strength } \\
\mathbf{R}_{\mathrm{m}} \\
{[\mathrm{MPa}]}\end{array}$ & $\begin{array}{c}\text { Yield } \\
\text { Strength } \\
R_{\mathrm{p} 0.2} \\
{[\mathrm{MPa}]}\end{array}$ & $\begin{array}{c}\text { Tensile } \\
\text { Strength } \\
\mathbf{R}_{\mathrm{m}} \\
{[\mathrm{MPa}]}\end{array}$ & $\begin{array}{c}\text { Yield } \\
\text { Strength } \\
\mathbf{R}_{\mathrm{p} 0.2} \\
{[\mathrm{MPa}]}\end{array}$ & $\begin{array}{c}\text { Tensile } \\
\text { Strength } \\
\mathbf{R}_{\mathrm{m}} \\
{[\mathrm{MPa}]}\end{array}$ \\
\hline 1 & 421 & 920 & 344 & 798 & 350 & 736 & 418 & 637 \\
\hline 2 & 426 & 926 & 338 & 805 & 346 & 700 & 421 & 645 \\
\hline 3 & 409 & 914 & 340 & 793 & 344 & 712 & 425 & 633 \\
\hline 4 & 458 & 937 & 341 & 794 & 350 & 716 & 423 & 661 \\
\hline 5 & 413 & 924 & 332 & 795 & 347 & 631 & 414 & 624 \\
\hline Aver. & 425 & 924 & 339 & 797 & 347 & 699 & 420 & 640 \\
\hline Stand. Dev. & 19.4 & 8.5 & 4.5 & 4.8 & 2.6 & 40.2 & 4.3 & 14.0 \\
\hline
\end{tabular}


Table 6. Cont.

(B) Elongation at fracture, (continued).

\begin{tabular}{|c|c|c|c|c|}
\hline Sample-No & As-Delivered [\%] & $\begin{array}{c}\text { Heat-Treated } \\
1200^{\circ} \mathrm{C} / 4 \mathrm{~h} \text { with } \\
\text { Contact Pressure [\%] }\end{array}$ & $\begin{array}{c}\text { Diffusion Bonded } \\
1200^{\circ} \mathrm{C} / 4 \mathrm{~h} / 10 \mathrm{MPa} \\
{[\%]}\end{array}$ & $\begin{array}{c}\text { Diffusion Bonded } \\
1200^{\circ} \mathrm{C} / 4 \mathrm{~h} / 10 \mathrm{MPa}+ \\
1000 \mathrm{~h} 70 \% \mathrm{H}_{2} \mathrm{SO}_{4} @ \\
100{ }^{\circ} \mathrm{C}[\%]\end{array}$ \\
\hline 1 & 85.1 & 96.2 & 53.5 & 18.7 \\
\hline 2 & 85.6 & 106.1 & 45.3 & 19.2 \\
\hline 3 & 88 & 102.6 & 48.2 & 18.3 \\
\hline 4 & 84.9 & 98 & 49.3 & 21.9 \\
\hline 5 & 81.9 & 99.1 & 30.9 & 21 \\
\hline Aver. & 85 & 100 & 45 & 20 \\
\hline Stand. Dev. & 2.2 & 4.0 & 8.6 & 1.6 \\
\hline
\end{tabular}

\subsubsection{Results of Tensile Tests on Hastelloy BC-1}

Generally, it is observed that the mechanical behavior of Hastelloy BC-1 in tension is comparable to that of Hastelloy B3. Only the strength of Hastelloy B3 is found to be slightly higher in all comparable conditions than the one of BC-1. In Figure 12, the results of the tests on as-delivered, heat-treated, and diffusion-bonded samples are presented. When comparing the as delivered condition of bulk material from Hasteloy BC- 1 with the heat-treated condition it can be seen that the annealed and compressed samples also show a decrease in strength of about $25 \%$ and an increase in ductility of about $20 \%$. The change in deformation behavior can be again traced back on both recovery and recrystallization/grain growth processes occurring during tempering.

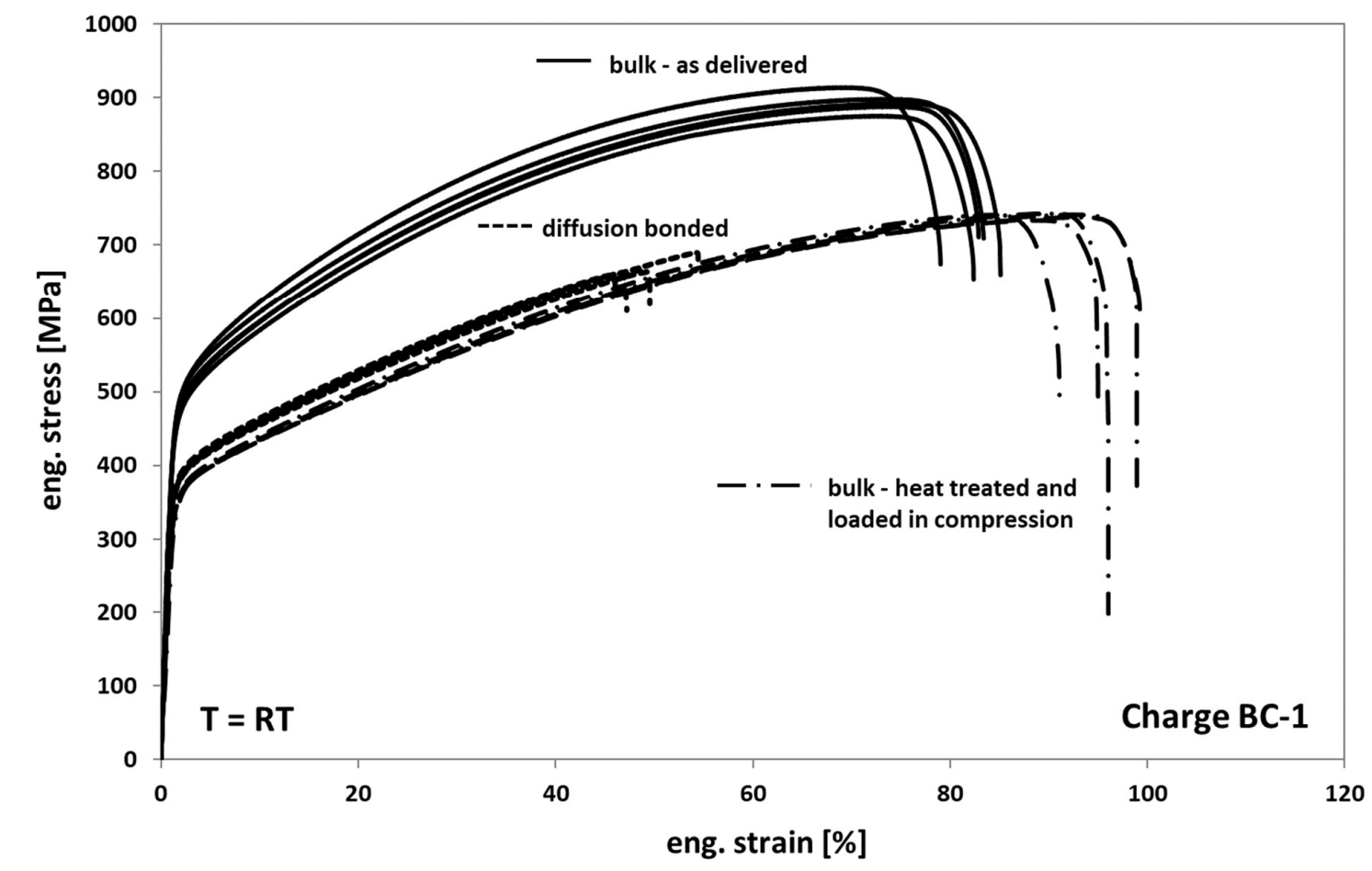

Figure 12. Tensile response of Hastelloy BC-1 in different conditions. 
Compared to the heat-treated bulk samples, the diffusion bonded samples also exhibit a comparable deformation behavior and a significant decrease in elongation at fracture of about $45 \%$ to $50 \%$. However, the scatter of the elongation at fracture values is clearly lower, indicating a more homogeneous distribution of weak spots and/or a lower variation of the entire size of non-bonded areas within the different bonding planes.

The fracture mode of all samples is also found to be ductile, at least in well bonded areas, but in contrast to Hastelloy B3, the dimples reveal a significant smaller size (compare Figure 9c and Figure 14b). In addition, identical to Hastelloy B3, small surface cracks in several other bonding planes are observed as already shown in Figure 9d.

When comparing the tensile test results of Hastelloy BC-1 obtained from tests on diffusion bonded samples, aged for $1000 \mathrm{~h}$ at $100{ }^{\circ} \mathrm{C}$ in $70 \%$ sulfuric acid to non-aged diffusion bonded samples (Figure 13), one can see a strong decrease of the elongation at fracture to $30 \%$. However, this is approximately $10 \%$ more than for Hastelloy B3 (Figure 10). For Hastelloy BC-1, in contrast to Hastelloy B3, the stress level of the aged samples is comparable to the non-aged samples. This behavior is obviously related to a less pronounced formation of an inhomogeneous distributed multiaxial stress-strain-field during loading, since the size of the corrosion cracks within the bonding planes is significant smaller compared to the sizes observed in Hastelloy B3-compare Figure 11a,c with Figure 14a,c. The much better corrosion resistance of Hastelloy BC-1 and the resulting low corrosion crack depths might reduce the effect of stress concentrations around the crack tips on the entire in plane stress distribution. As a result, related to Hastelloy B3, the onset of failure is shifted towards higher elongation at fracture values.

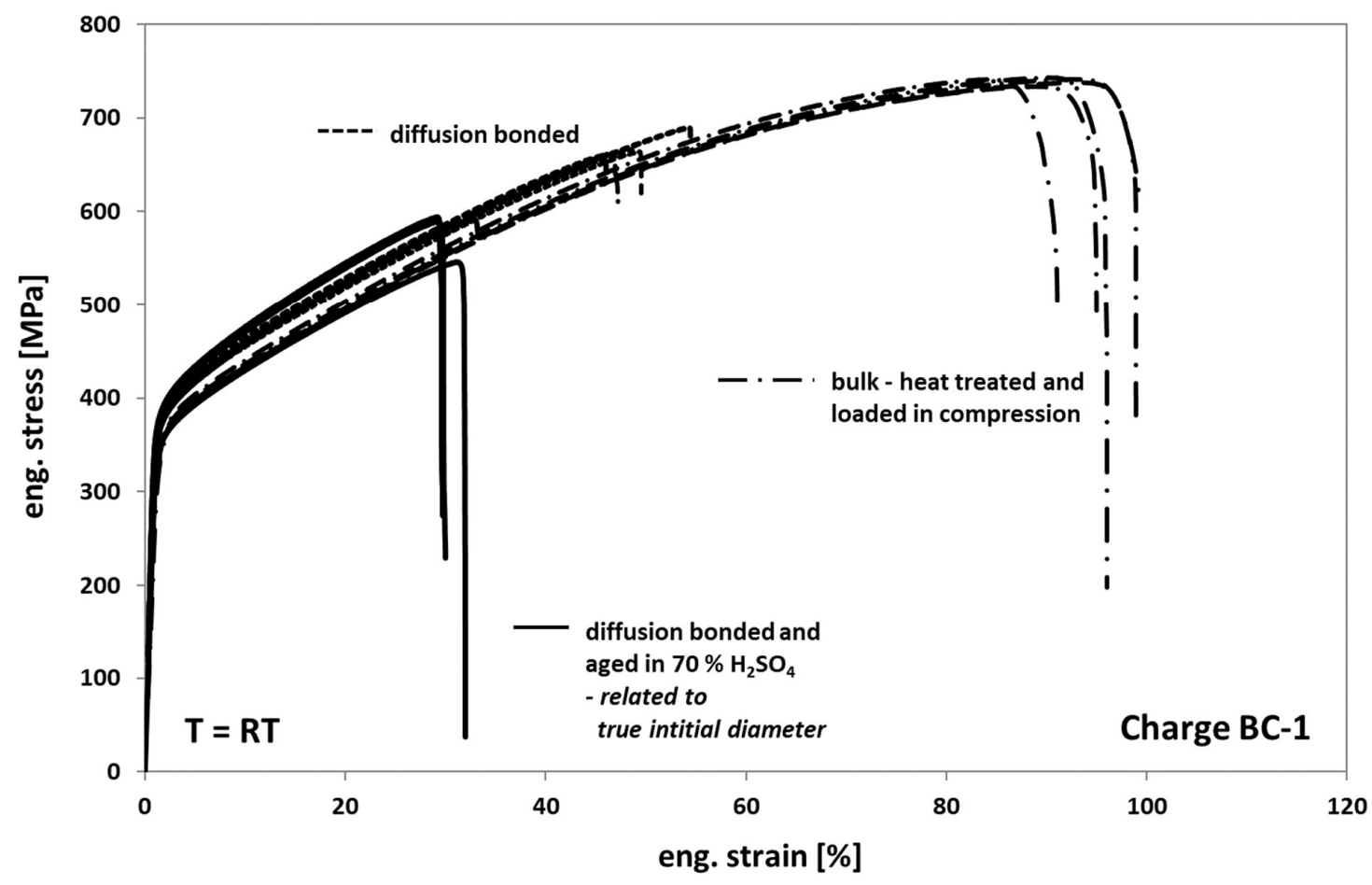

Figure 13. Tensile response of Hastelloy BC-1 in different conditions. 

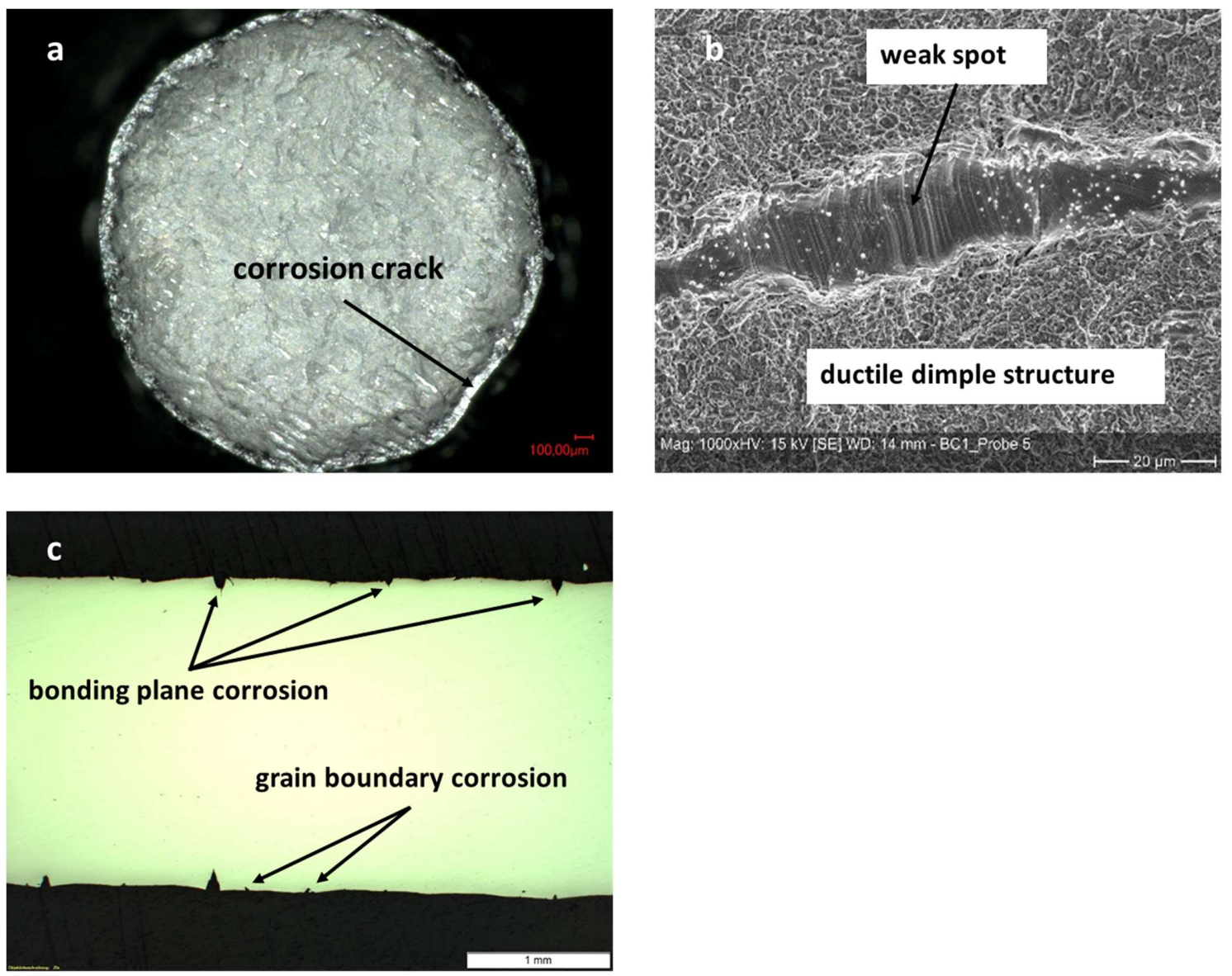

Figure 14. Micrographs of tensile tested diffusion bonded and aged $\left(1000 \mathrm{~h}\right.$ at $100{ }^{\circ} \mathrm{C}$ in $70 \%$ sulfuric acid) samples made of Hastelloy BC-1. (a): Overview of fracture surface displaying corrosion attack depth. (b): Detailed view of the fracture surface showing non-bonded area and slip bands as well as dimples. (c): Longitudinal cut along center of failed sample. Pronounced corrosion at bonding planes and some intergranular corrosion can be seen.

An overview of the obtained mechanical properties of all tested specimens is given in Table 7. The obtained stresses are related to the true initial cross-sections.

Table 7. Mechanical properties of Hastelloy BC-1 in different conditions.

(A) Yield strength and tensile strength.

\begin{tabular}{|c|c|c|c|c|c|c|c|c|}
\hline \multirow{2}{*}{ Sample-No } & \multicolumn{2}{|c|}{ As-Delivered } & \multicolumn{2}{|c|}{$\begin{array}{c}\text { Heat-Treated } \\
1200{ }^{\circ} \mathrm{C} / 4 \text { h with } \\
\text { Contact Pressure }\end{array}$} & \multicolumn{2}{|c|}{$\begin{array}{l}\text { Diffusion Bonded } \\
1200^{\circ} \mathrm{C} / 4 \mathrm{~h} / 10 \mathrm{MPa}\end{array}$} & \multicolumn{2}{|c|}{$\begin{array}{c}\text { Diffusion Bonded } \\
1200{ }^{\circ} \mathrm{C} / 4 \mathrm{~h} / 10 \mathrm{MPa}+ \\
1000 \mathrm{~h} 70 \% \mathrm{H}_{2} \mathrm{SO}_{4} @ \\
100{ }^{\circ} \mathrm{C}\end{array}$} \\
\hline & $\begin{array}{c}\text { Yield } \\
\text { Strength } \\
\mathbf{R}_{\mathrm{p} 0.2} \\
{[\mathrm{MPa}]}\end{array}$ & $\begin{array}{c}\text { Tensile } \\
\text { Strength } \\
\mathbf{R}_{\mathrm{m}} \\
{[\mathrm{MPa}]}\end{array}$ & $\begin{array}{c}\text { Yield } \\
\text { Strength } \\
\mathbf{R}_{\mathrm{p} 0.2} \\
{[\mathrm{MPa}]}\end{array}$ & $\begin{array}{c}\text { Tensile } \\
\text { Strength } \\
\mathbf{R}_{\mathrm{m}} \\
{[\mathrm{MPa}]}\end{array}$ & $\begin{array}{c}\text { Yield } \\
\text { Strength } \\
\mathbf{R}_{\mathrm{p} 0.2} \\
{[\mathrm{MPa}]}\end{array}$ & $\begin{array}{c}\text { Tensile } \\
\text { Strength } \\
\mathbf{R}_{\mathrm{m}} \\
{[\mathrm{MPa}]}\end{array}$ & $\begin{array}{c}\text { Yield } \\
\text { Strength } \\
\mathbf{R}_{\mathrm{p} 0.2} \\
{[\mathrm{MPa}]}\end{array}$ & $\begin{array}{c}\text { Tensile } \\
\text { Strength } \\
\mathbf{R}_{\mathrm{m}} \\
{[\mathrm{MPa}]}\end{array}$ \\
\hline 1 & 430 & 892 & 325 & 741 & 341 & 660 & 334 & 547 \\
\hline 2 & 449 & 914 & 326 & 733 & 338 & 690 & 358 & 590 \\
\hline 3 & 436 & 888 & 318 & 737 & 338 & 664 & 349 & 592 \\
\hline 4 & 441 & 898 & 317 & 743 & 339 & 663 & 362 & 590 \\
\hline 5 & 422 & 876 & 325 & 741 & 337 & 667 & 362 & 594 \\
\hline Aver. & 436 & 894 & 322 & 739 & 339 & 669 & 353 & 583 \\
\hline Stand. Dev. & 10.3 & 14.0 & 4.3 & 4.0 & 1.5 & 12.1 & 11.9 & 20.0 \\
\hline
\end{tabular}


Table 7. Cont.

(B) Elongation at fracture, (continued).

\begin{tabular}{|c|c|c|c|c|}
\hline Sample-No & As-Delivered [\%] & $\begin{array}{c}\text { Heat-Treated } \\
1200{ }^{\circ} \mathrm{C} / 4 \mathrm{~h} \text { with } \\
\text { Contact Pressure [\%] }\end{array}$ & $\begin{array}{c}\text { Diffusion Bonded } \\
1200{ }^{\circ} \mathrm{C} / 4 \mathrm{~h} / 10 \mathrm{MPa} \\
{[\%]}\end{array}$ & $\begin{array}{c}\text { Diffusion Bonded } \\
1200{ }^{\circ} \mathrm{C} / 4 \mathrm{~h} / 10 \mathrm{MPa}+ \\
1000 \mathrm{~h} 70 \% \mathrm{H}_{2} \mathrm{SO}_{4} @ \\
100{ }^{\circ} \mathrm{C}[\%]\end{array}$ \\
\hline 1 & 85.1 & 104.9 & 46 & 32 \\
\hline 2 & 79 & 98.2 & 54.4 & 29.2 \\
\hline 3 & 82.9 & 89.5 & 49.5 & 33.2 \\
\hline 4 & 83.4 & 94.3 & 47.2 & 30 \\
\hline 5 & 82.4 & 88.5 & 48.7 & 29.7 \\
\hline Aver. & 83 & 95 & 49 & 31 \\
\hline Stand. Dev. & 2.2 & 6.7 & 3.2 & 1.7 \\
\hline Min & 79.0 & 88.5 & 46.0 & 29.2 \\
\hline Max & 85.1 & 104.9 & 54.4 & 33.2 \\
\hline
\end{tabular}

\subsubsection{Comparison of Heat Treated and Diffusion Bonded Conditions to Delivery Condition}

The tough behavior of nickel-base alloys in combination with their cubic face-centered lattice generally leads to very high elongation at fracture values for both alloys. As delivered and heat-treated, the tensile strength is about twice as high as the yield strength due to cold work hardening effects during tensile tests (Tables 6 and 7).

Due to the temperature level and dwell time during diffusion bonding, any pre-work hardening is lost. The values for yield strength and tensile strength drop to $75-80 \%$ of the values obtained on delivery condition (Table 8).

Table 8. Decrease of strength properties of Hastelloy B3 and BC-1 related to delivery condition.

\begin{tabular}{|c|c|c|c|c|c|c|c|}
\hline \multicolumn{4}{|c|}{ Heat-Treated $1200{ }^{\circ} \mathrm{C} / 4 \mathrm{~h}$ with Contact Pressure } & \multicolumn{4}{|c|}{ Diffusion Bonded $1200{ }^{\circ} \mathrm{C} / 4 \mathrm{~h} / 10 \mathrm{MPa}$} \\
\hline \multicolumn{2}{|c|}{ B3 } & \multicolumn{2}{|c|}{ BC-1 } & \multicolumn{2}{|c|}{ B3 } & \multicolumn{2}{|c|}{ BC-1 } \\
\hline $\begin{array}{c}\text { Yield } \\
\text { Strength } \\
\mathrm{R}_{\mathrm{p} 0.2}(\%)\end{array}$ & $\begin{array}{c}\text { Tensile } \\
\text { Strength } \\
\mathbf{R}_{\mathrm{m}}(\%)\end{array}$ & $\begin{array}{c}\text { Yield } \\
\text { Strength } \\
\mathrm{R}_{\mathrm{p} 0.2}(\%)\end{array}$ & $\begin{array}{c}\text { Tensile } \\
\text { Strength } \\
\mathbf{R}_{\mathrm{m}}(\%)\end{array}$ & $\begin{array}{c}\text { Yield } \\
\text { Strength } \\
\mathrm{R}_{\mathrm{p} 0.2}(\%)\end{array}$ & $\begin{array}{c}\text { Tensile } \\
\text { Strength } \\
\mathbf{R}_{\mathrm{m}} \mathbf{( \% )}\end{array}$ & $\begin{array}{c}\text { Yield } \\
\text { Strength } \\
\mathrm{R}_{\mathrm{p} 0.2}(\%)\end{array}$ & $\begin{array}{c}\text { Tensile } \\
\text { Strength } \\
\mathbf{R}_{\mathrm{m}}(\%)\end{array}$ \\
\hline 79.7 & 86.2 & 74.0 & 82.7 & 81.7 & 75.6 & 77.7 & 74.8 \\
\hline
\end{tabular}

\section{Conclusions and Outlook}

Within this study, both the effect of diffusion bonding process on the mechanical properties, and the corrosion resistance against hot 70\% sulfuric acid of Hastelloy B3 and Hastelloy BC-1 was found to be better than previously investigated alloys. Although the grain growth crossing bonding planes during diffusion bonding is not fully satisfactory, both materials achieve sufficiently high elongation at fracture values for engineering applications.

The deformation of about $2 \%$ achieved at diffusion bonding of samples for tensile tests is not yet sufficient for eliminating all surface defects. Defects promote crack formation and propagation. The deformation until fracture decreases. Recently, the elongation at fracture values of diffusion bonded samples for both materials are significantly reduced. Depending on the design of devices, bonding parameters - mainly bearing pressure and bonding temperature-should be optimized to obtain a slightly increased deformation.

Diffusion bonded tensile test samples of both alloys aged in $70 \%$ sulfuric acid at $100{ }^{\circ} \mathrm{C}$ for $1000 \mathrm{~h}$, show only a low corrosion attack compared to other materials investigated so far, especially Hastelloy C-22. For Hastelloy B3 (2.4600), however, the corrosion attack is more pronounced than for Hastelloy BC-1 (2.4708) despite its higher molybdenum content. This is in accordance with the results from the beaker tests (Table 4). Therefore, only Hastelloy BC-1 represents an interesting solution for use in micro process devices for hot diluted sulfuric acid. 
Obviously, the higher chromium content of Hastelloy BC-1 leads to higher corrosion resistance. It is not understood why in earlier investigations the material Alloy $2120 \mathrm{MoN}$ (2.4700), which has a very similar composition to Hastelloy BC-1, did not perform comparably well, especially after aging in $70 \%$ sulfuric acid in heat-treated condition (Table 1 ).

In comparison to solely diffusion bonded condition, the elongation at fracture of samples aged in $70 \%$ sulfuric acid at $100{ }^{\circ} \mathrm{C}$ for six weeks decreased to $20 \%$ and $30 \%$ for Hastelloy B3 and Hastelloy BC-1, respectively. These values are still sufficient for use of these materials in micro process apparatuses. However, it shows that the impact of corrosion in micro process technology may not be neglected for long-term use. Standardized corrosion tests such as ASTM G28-A with special electrolytes and short test duration do not provide sufficient information concerning corrosion for micro process devices.

In contrast to the findings in this study, corrosion data from the data sheets of Hastelloy B3 and Hastelloy BC-1 for sulfuric acid of different concentrations suggested that Hastelloy B3 should be more resistant to corrosion. This is surprising so far as the joining temperature of $1200{ }^{\circ} \mathrm{C}$ for both materials is above the recommended solution annealing temperatures. Sensitization therefore was only expected during the cooling phase in high vacuum.

Both Ni-base alloys, due to their high content of molybdenum, have a low coefficient of thermal expansion, which is close to that of ferritic steels. Therefore, they may be considered as an alternative to ferritic stainless steels, in particular for combining with zirconium oxide, used as a diffusion or thermal barrier layer, if improved corrosion resistance of the matrix material is required.

Author Contributions: Conceptualization, T.G. and M.W.; methodology, T.G.; investigation, V.T., F.M. and R.D.; data curation, M.W., T.G., R.D; writing—original draft preparation, T.G. and M.W.; writing—review and editing, T.G.; visualization, M.W. and T.G.; supervision, T.G. and M.W. All authors have read and agreed to the published version of the manuscript.

Funding: Financial support under the Helmholtz Programme SCI (Storage Systems and Cross-linked Infrastructures) is gratefully acknowledged.

Conflicts of Interest: The authors declare no conflict of interest.

\section{References}

1. Hayes, J.R.; Gray, J.; Szmodis, A.W.; Orme, C.A. Influence of Chromium and Molybdenum on the Corrosion of Nickel-Based Alloys. Corrosion 2006, 62, 491-500. [CrossRef]

2. Ha, H.-Y.; Lee, T.-H.; Bae, J.-H.; Chun, D.W. Molybdenum Effects on Pitting Corrosion Resistance of FeCrMnMoNC Austenitic Stainless Steels. Metals 2018, 8, 653. [CrossRef]

3. Alves, H.; Behrens, R.; Paul, L. Evolution of Nickel Base Alloys-Modification to Traditional Alloys for Specific Applications. In Proceedings of the Corrosion, San Antonio, TX, USA, 9-13 March 2014.

4. Heubner, U.; Koehler, M. Das Zeit-Temperatur-Ausscheidungs- und das Zeit-Temperatur-Sensibilisierungs-Verhalten von hoch korrosionsbeständigen Nickel-Chrom-Molybdan-Legierungen. Mater. Corros. 1992, 43, 181-190. [CrossRef]

5. Agarwal, D.C.; Herda, W.R. The "C" family of Ni-Cr-Mo allos' partnership with the Chemical Process Industry: The last 70 years. Mater. Corros. 1997, 48, 542-548. [CrossRef]

6. Final report of AiF-Project No. 18034. Untersuchungen zur Verbesserung der Korrosionsbeständigkeit mikroverfahrenstechnischer Bauteile für aggressive chemische Prozessmedien. 1 February 2014-30 September 2016. Available online: http://www.imvt.kit.edu/downloads/AiF_Abschlussbericht_20170117_gie.pdf (accessed on 14 February 2020).

7. Gietzelt, T.; Kraut, M.; Messerschmidt, F.; Fürbeth, W.; Dittmeyer, R. Corrosion-Resistant Microprocess Apparatuses by Means of CVD Coating with Tantalum. Chem. Ing. Techn. 2018, 90, 1037-1046. [CrossRef]

8. Data Sheet of Hastelloy B3. Available online: https://www.haynesintl.com/docs/default-source/pdfs/newalloy-brochures/corrosion-resistant-alloys/brochures/pdf-alloy-b-3.pdf?sfvrsn=14 (accessed on 20 February 2020).

9. Data Sheet of Hastelloy BC-1. Available online: https://www.haynesintl.com/docs/default-source/pdfs/newalloy-brochures/corrosion-resistant-alloys/brochures/hybrid-bc1.pdf?sfvrsn=14 (accessed on 14 February 2020). 
10. Data Sheet of Nicrofer 5821 hMoN. Available online: https://www.vdm-metals.com/fileadmin/user_upload/ Downloads/Data_Sheets/Datenblatt_VDM_Alloy_2120.pdf (accessed on 14 February 2020).

11. Koehler, M. Besondere Aspekte der Temperaturführung und Wärmebehandlung hochlegierter Werkstoffe für den Chemie-Apparatebau. Mater. Corros. 1997, 48, 528-534. [CrossRef]

12. Heinemann, J.; Richli, C. A comparative investigation of weld filler materials Alloy C22 and Alloy 59. Mater. Corros. 2001, 52, 106-111. [CrossRef]

13. Mori, G.; Sutthirungwong, S.; Czery, M.; Partlic, T. Metallurgical and Surface Influence on the Corrosion Resistance of Ni-Cr-Mo Alloys According to ASTM G 28. Corrosion 2004, 60, 1082-1091. [CrossRef]

14. ASTM G28: Standard Test Methods for Detecting Susceptibility to Intergranular Corrosion in Wrought, Nick-el-Rich, Chromium-Bearing Alloys; ASTM International: West Conshohocken, PA, USA, 2008.

15. Gietzelt, T.; Toth, V.; Huell, A.; Dittmeyer, R. Determining the Dependence of Deformation during Diffusion Welding on the Aspect Ratio Using Samples Made of SS 304 (1.4301). Adv. Eng. Mater. 2017, 19. [CrossRef]

16. Li, X.; Kininmont, D.; le Pierres, R.; Dewson, S.J. Alloy 617 for the High Temperature Diffusion-Bonded Compact Heat Exchangers. In Proceedings of the ICAPP, Anaheim, CA, USA, 8-12 June 2008; pp. 282-288.

(C) 2020 by the authors. Licensee MDPI, Basel, Switzerland. This article is an open access article distributed under the terms and conditions of the Creative Commons Attribution (CC BY) license (http://creativecommons.org/licenses/by/4.0/). 